\title{
Relation between Melatonin and Other Markers of Oxidant/Antioxidant Status in Epileptic Children: Effect of Valproate Therapy
}

\author{
Aisha S. Eid*, Omneya G. Afify**, Amira A. Idris**, \\ Layla A. Sleem**, Heba El Salamony and Jihan H. Ibraheim. \\ Departments of Medical Biochemistry* and Pediatrics ** \\ Faculty of Medicine, Cairo University.
}

\begin{abstract}
The aim of the present work was to investigate the relationship between serum melatonin levels and other markers of oxidant/antioxidant balance in epileptic children before and after treatment with the antiepileptic drug valproic acid (VPA). The study was conducted on twenty epileptic children prior to starting therapy, as well as on another twenty age and sex matched epileptic children receiving treatment with the antiepileptic drug VPA, for a minimum duration of one year. Fifteen age and sex matched healthy children were included as a control group. Serum melatonin, zinc, copper, and malondialdehyde (MDA) concentrations and erythrocyte superoxide dismutase (SOD) activity were measured in all subjects. Mean levels of melatonin and MDA were significantly increased while SOD activity was significantly decreased in both untreated and treated epileptics versus control. However, the melatonin and SOD were significantly lower in treated versus untreated epileptics. The serum zinc levels were significantly lower while the serum copper levels were significantly higher in treated versus untreated epileptics. Melatonin was negatively correlated to MDA and copper and positively correlated to SOD. It thus seems possible that oxidant stress is associated with epilepsy and is aggravated with VPA therapy leading to relative reduction in melatonin (in treated versus untreated epileptics) and absolute reduction in erythrocytic SOD and serum zinc concentrations.
\end{abstract}

Key Words: Epilepsy, serum melatonin, zinc, copper, and malondialdehyde (MDA,) erythrocyte superoxide dismutase (SOD), antiepileptic drug valproic acid (VPA).

\section{INTRODUCTION}

Epilepsy is a chronic disorder characterized by unprovoked, recurring seizures that disrupt the nervous system and can cause mental and physical dysfunction. It affects all age groups. The incidence is highest in children with another but lesser peak occurring after the age of 60 years $^{(1,2)}$. Approximately $10-30 \%$ of patients with epilepsy continue to have seizures despite medical treatment. Seizures are thought to be the result of an imbalance of neurochemicals and are associated with the production of free radicals which can damage brain cells ${ }^{(3,4)}$. The brain is especially vulnerable to oxyradical injury due to its high oxygen consumption rate, its abundant lipid 
content, and the relative paucity of antioxidant enzymes compared with other tissues ${ }^{(5)}$. The antioxidant enzymes $\mathrm{CuZn}$-superoxide dismutase (SOD), Mn-SOD and glutathione peroxidase are present in intermediate amounts, and the catalase activity is very low. Thus, the glial and neuronal cells may be prone to oxidative stress which has been implicated as a contributory factor in various neurological disorders ${ }^{(6)}$.

It is widely accepted that trace elements play an important role in various metabolic processes, and zinc $(\mathrm{Zn})$, copper $(\mathrm{Cu})$ and selenium $(\mathrm{Se})$ are known to be necessary for the activity of some enzymes. Although many authors have demonstrated an association between some trace elements and epilepsy, the relation has never been convincingly documented, because the data in the literature are conflicting. Moreover, little is known about the changes in trace elements induced by antiepileptic drugs $(\mathrm{AEDs})^{(7)}$.

Melatonin, a neuromodulator produced by the pineal gland, has been shown to have antiepileptic activities in animal studies using several seizure models ${ }^{\left({ }^{(8)}\right.}$ as well as in cases of childhood epilepsy ${ }^{(\mathbf{9})}$. A few mechanisms for anticonvulsant activity of melatonin have been suggested. It exerts neuroprotection due to its antioxidant, anti-excitotic and free radical scavenging properties within the central nervous system $^{(\mathbf{1 0 , 1 1 , 1 2})}$. The function of melatonin as an antioxidant and free radical scavenger is facilitated by the ease with which it crosses morphophysiological barriers, as the blood-brain barrier and intracellular and subcellular barriers ${ }^{(13,14)}$.

Carbamazepine (CBZ) and valproic acid (VPA) are widely used as antiepileptic drugs (AEDs) that are effective in treating different forms of epilepsy. Recent studies have indicated that AEDs, especially VPA, may trigger oxygen dependant tissue injury by several mechanisms. It is suggested that VPA impairs the liver function resulting in free radicals production. The latter seems to produce DNA oxidative damage in cells, including neuronal cells ${ }^{(15)}$. VPA may, also, compromise the antioxidant system. ${ }^{(4)}$.

The aim of the present study was to evaluate the oxidant/antioxidant status in patients with epilepsy as represented by the levels of malondialdehyde (MDA: as a marker of lipid peroxidation), the antioxidants melatonin and superoxide dismutase, and the trace elements copper and zinc in erythrocyte and serum samples of patients with epilepsy. In addition, the effect of therapy with the antiepileptic drug valproic acid on the oxidant/antioxidant status was, also, evaluated. Melatonin (as a neuromodulator, not only an antioxidant) will be correlated to the other parameters studied.

\section{SUBJECTS \& METHODS}

The study included 40 epileptic patients with generalized tonic-clonic seizures, chosen from the Neurology Clinic in Abu El Reish Pediatric Hospital, Cairo University. Their ages ranged between 3 and 12 years, and there were 18 males and 22 females. The 40 patients included: (I) 20 newly 
diagnosed epileptic children prior to the administration of any form of antiepileptic drug (AED), their mean age \pm S.D. was $6.6 \pm 3.9$ years, and (II) 20 epileptic children on treatment with the AED Valproic acid for a minimum period of one year. Their mean age \pm S.D. was $7.4 \pm 3.2$ years. All patients were in the interictal period, or at least $12 \mathrm{hrs}$. seizure free from sampling time. Excluded from the study were children suffering from progressive brain disease or chronic medical or surgical illness or those receiving chronic medication other than the AED valproic acid. Fifteen normal healthy children (age and sex matched) served as a control group. Their mean age \pm S.D. was $7.6 \pm 3.1$ years. Detailed information on the study was given to each patient or subject and their accompanying relative, and a written consent to participate in the study was obtained.

All patients were subjected to full clinical examination and electroencephalographic study. The children were under normal daily light-dark cycles. From each case 10 $\mathrm{ml}$ venous blood was collected at about 10 p.m. Light remained dim during that nocturnal sampling. The blood sample was divided into two parts: one part was allowed to clot at room temperature and centrifuged at $5000 \mathrm{rpm}$ for $10 \mathrm{~min}$ and the serum was collected, and aliquots of that serum were kept frozen at $-70^{\circ} \mathrm{C}$. The second part of the blood sample was collected in a tube containing heparin, centrifuged, and the retrieved erythrocytes were washed thrice with cold physiological saline and lysed with double distilled water prior to analysis for hemoglobin and SOD estimation.

All patients and controls were subjected to the following biochemical investigations:

1. The quantitative estimation of some serum trace elements $\left(\mathrm{Zn}^{2+}\right.$ and $\mathrm{Cu}^{2+)}$ were measured by the atomic absorption spectrophotometer (UNICAM, 939/959). Sera were diluted 10 times with distilled water. The analysis wavelengths were 213.9 and $324.7 \mathrm{~nm}$, respectively.

2. Serum malondialdehyde (MDA) (the most abundant degradation product of lipid peroxidation as a marker of lipid peroxidation). The principle of the method was based on the spectrophotometric measurement of the color adduct occurring during the reaction to thiobarbituric acid with malondialdehyde whose absorbance is measured at $530 \mathrm{~nm}^{(\mathbf{1 6})}$.

3. Hemoglobin concentration was assessed by conventional methods.

4. Superoxide dismutase (SOD) was assessed using the Ransod kit (Antrim, U.K.) ${ }^{(17)}$.

5. Serum melatonin level was quantitatively determined by an enzyme immunoassay method using the kit supplied by IBL Hamburg. Extraction was first determined in C18 reversed phase extraction column by applying the serum samples with $10 \%$ methanol in bidistilled water $(\mathrm{V} / \mathrm{V})$ and eluting with undiluted methanol followed by evaporation of methanol to dryness using liquid nitrogen then reconstitution of the samples with distilled water. ${ }^{(\mathbf{1 8})}$. 


\section{Statistical analyses:}

Data are expressed as means \pm S.D. Statistical comparison among different groups was performed using the one way analysis of variance (ANOVA) test followed by post-hoc test. To assess the relationship between the different studied biochemical parameters Pearson's correlation was used. Calculations were done using the statistical package SPSS for Windows, version 10.0. Statistical significance was defined as $p<0.05$.

\section{RESULTS}

The results of the present study are shown in table (1) and figures (15).

The mean levels \pm S.D. of both serum melatonin and MDA showed a significant increase while that of erythrocytic SOD showed a significant decrease in untreated epileptics versus controls. The melatonin mean level then showed a significant decrease in the epileptic patients receiving treatment with VPA as compared to the untreated epileptic group. However, that decreased melatonin level was still significantly higher than that of the control group. Meanwhile, the mean level of MDA further significantly increased while the SOD mean levels further significantly decreased in the epileptic patients treated with VPA compared to both controls and untreated epileptics.

The mean serum zinc level was significantly lower while the mean serum copper was significantly higher in the treated epileptics versus both controls and untreated epileptics.

Significant negative correlation was detected between melatonin and MDA $(r=-0.65)$, while a significant positive correlation was detected between melatonin and SOD $(\mathrm{r}=$ 0.52 ). Negative correlations were detected between MDA and each of SOD $(r=-0.59)$ and zinc $(r=-0.53)$. Meanwhile, MDA was positively correlated with copper $(\mathrm{r}=0.61)$. Also, other negative correlations were detected between serum zinc and copper levels $(\mathrm{r}=-0.58)$ and between melatonin and copper $(r=-0.43)$.

Table (1): Serum melatonin, malondialdehyde (MDA), zinc and copper and erythrocytic superoxide dismutase (SOD) in various study groups.

\begin{tabular}{|l|c|c|c|}
\hline & $\begin{array}{c}\text { Control } \\
(\mathbf{n}=\mathbf{1 5})\end{array}$ & $\begin{array}{c}\text { Untreated Epileptics } \\
(\mathbf{n}=\mathbf{2 0})\end{array}$ & $\begin{array}{c}\text { Treated Epileptics } \\
(\mathbf{n}=\mathbf{2 0})\end{array}$ \\
\hline Melatonin $(\mathrm{pg} / \mathrm{mL})$ & $32.7 \pm 8.5$ & $165.2 \pm 102.4$ (a) & $83.8 \pm 40$ (a) (b) \\
\hline MDA $(\mathrm{nmol} / \mathrm{mL})$ & $3 \pm 0.7$ & $5.5 \pm 0.9(\mathbf{a})$ & $6.5 \pm 1.1(\mathbf{a})(\mathbf{b})$ \\
\hline SOD $(\mathrm{U} / \mathrm{gHb})$ & $965.3 \pm 120.4$ & $853.5 \pm 116.7(\mathbf{a})$ & $733.5 \pm 139.7(\mathbf{a})(\mathbf{b})$ \\
\hline Zinc $(\mu \mathrm{g} / \mathrm{dL})$ & $94.4 \pm 10.6$ & $88.8 \pm 9.5$ & $71.6 \pm 12$ (a) (b) \\
\hline Copper $(\mu \mathrm{g} / \mathrm{dL})$ & $93.6 \pm 9.9$ & $97.5 \pm 14.9$ & $126.1 \pm 19.4$ (a) (b) \\
\hline
\end{tabular}

- Values are expressed as mean \pm S.D.

- (a): denotes significant difference between patient group and the control $(p<0.05)$

- (b): denotes significant difference between treated and untreated epileptic patients $(p<0.05)$. 


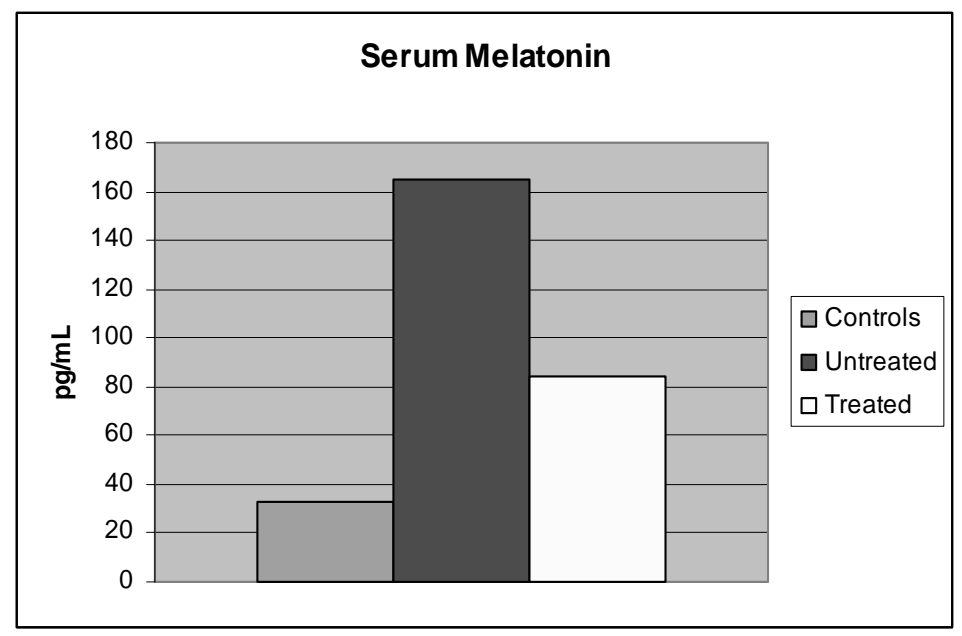

Figure (1): Serum melatonin levels in the different study groups.

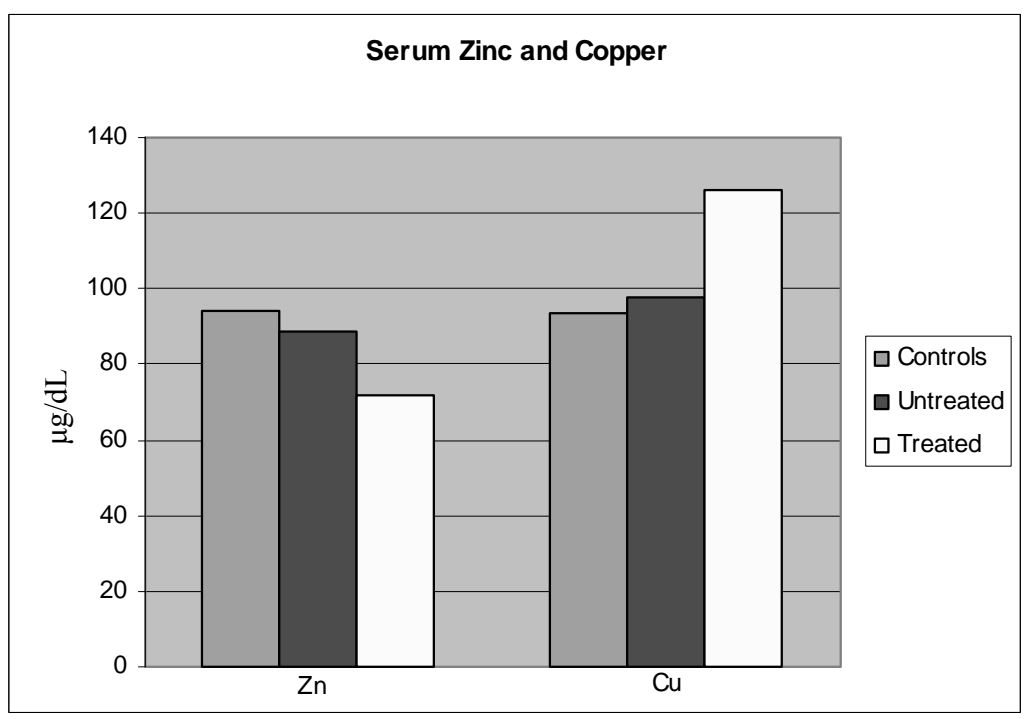

Figure (2): Serum Zinc and Copper levels in the different study groups. 


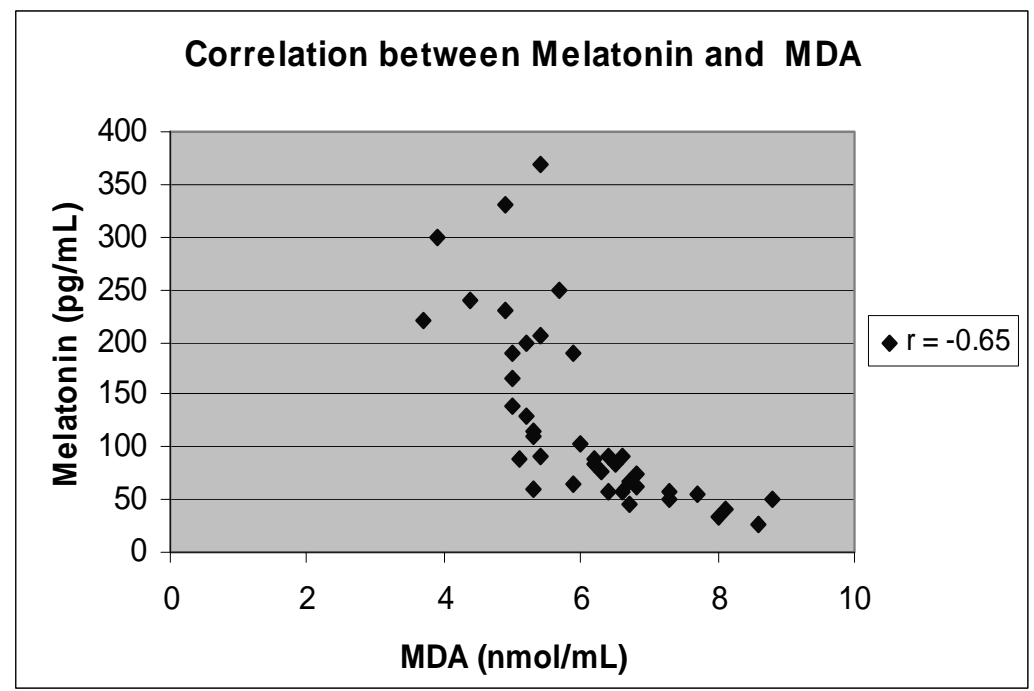

Figure (3): Scatter plot showing the correlation between serum melatonin and malodialdehyde (MDA) levels.

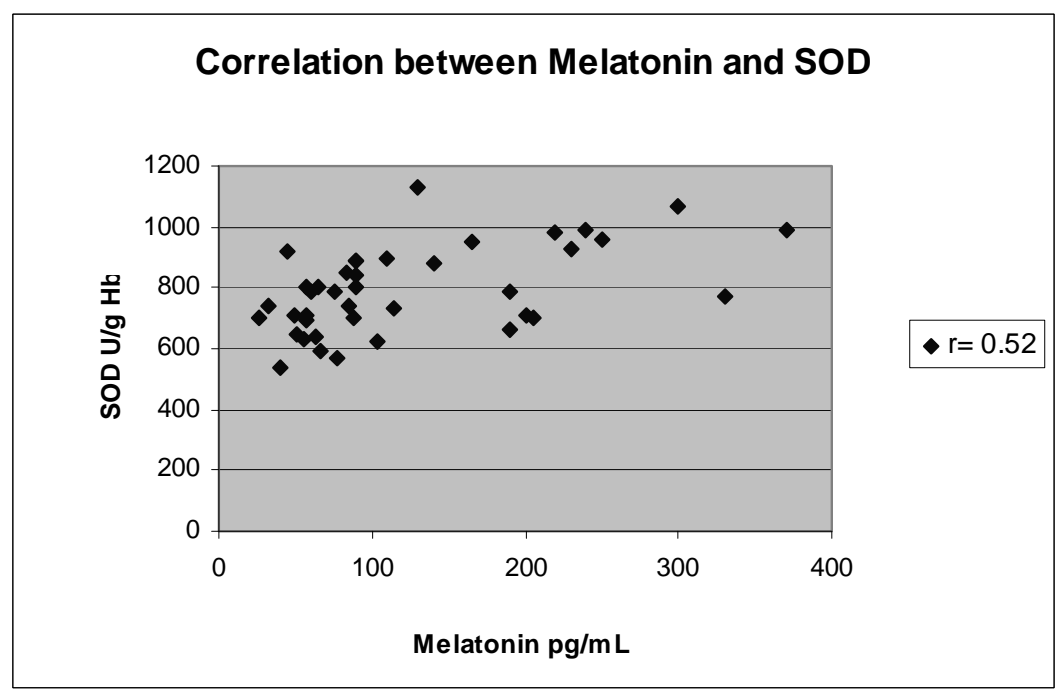

Figure (4): Scatter plot showing the correlation between serum melatonin and superoxide dismutase (SOD) levels. 


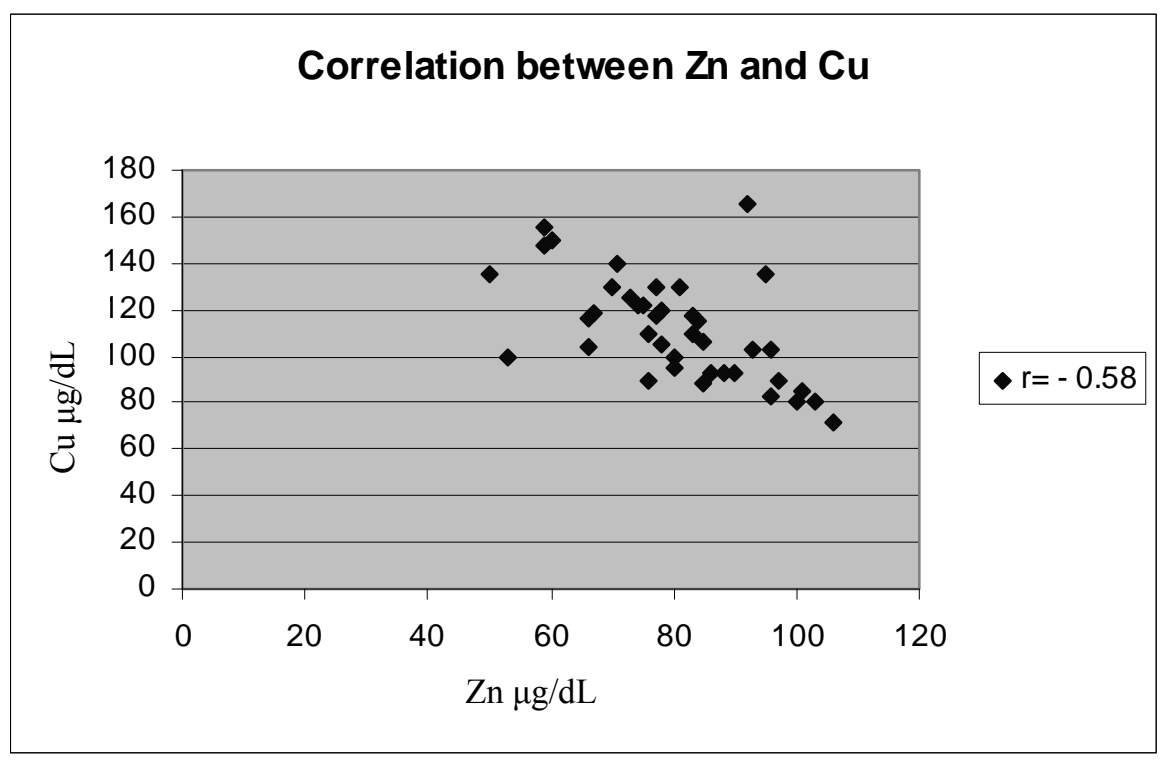

Figure (5): Scatter plot showing the correlation between serum zinc (Zn) and Copper (Cu) levels.

\section{DISCUSSION}

Evidence has accumulated about the involvement of reactive oxygen species (ROS) in epilepsy ${ }^{(19)}$. MDA levels showed significant increase in the untreated children compared to the MDA levels in the controls. MDA levels showed further significant increase in the treated patients receiving the antiepileptic drug (AED) valproic acid (VPA) indicating that the metabolism of VPA may trigger oxygen dependent tissue injury and elevate free radicals in the body ${ }^{(4,20)}$. These free radicals cause a cascade of neurochemical events leading to neurodegeneration and cell death ${ }^{(21)}$. Long-term use of AEDs has been shown to increase free radical formation and cause oxidative damage within neuronal cells ${ }^{(20)}$. It was previously reported that VPA may have different effects on the antioxidant system ${ }^{(4,20,22)}$. Moreover, VPA enhances the clearance of selenium and zinc, subsequently leading to decreased synthesis of free radical scavenging enzymes ${ }^{(23,12)}$.

The present results showed a significant increase in the mean serum levels of melatonin in both untreated and treated epileptic children compared to controls; however, the levels in the treated children were significantly lower than the levels in the untreated children. In addition, melatonin was negatively correlated to MDA and $\mathrm{Cu}^{2+}$. 
The current findings are in accordance with those of Graham et al., who demonstrated that melatonin levels were high in unmedicated patients with complex partial epilepsy $^{(24)}$. Overproduction of melatonin may possibly be an attempt by the brain cells to produce a natural downregulator of cerebral epileptiform activity. Melatonin appears to enhance the major neurochemical GABA, whose function is to stop or inhibit seizures. In addition, melatonin blocks the neurochemical glutamate which promotes seizures (25). Lastly, melatonin is an anti-oxidant which means that it blocks the bad effects of free radicals which may cause brain damage. Melatonin scavenges oxygen free radicals like superoxide radical, hydroxyl radical, peroxyl radical and peroxynitrite anion. Melatonin can, also, enhance the antioxidative potential of the cell by stimulating the synthesis of antioxidative enzymes like superoxide dismutase (SOD), glutathione peroxidase, and, also, the enzymes that are involved in the synthesis of glutathione (26). In many instances, melatonin increases the expression of $m$ RNA's of the antioxidative enzymes ${ }^{(27)}$. Such finding is confirmed, in the present study, by the decrease in the erythrocytic SOD in the treated epileptics more than the untreated children where the melatonin levels were lower. It is also confirmed by the positive correlation between melatonin and SOD. However, Sandyk et al. $^{\text {(28) }}$ demonstrated that high doses of melatonin may exert proconvulsive activity by decreasing hypothalamic and cortical GABA levels (25)

The results of melatonin levels in the epileptic group receiving VPA are in accordance with the findings of Bazil et al. (29). Lower levels of melatonin, could possibly be attributed to the oxidant status induced by the anticonvulsant drug VPA ${ }^{(15)}$. This could have contributed to the decrease in melatonin levels found in medicated epileptics compared to untreated ones. Melatonin may thus be consumed by the oxidative process induced by VPA. Gupta et al., ${ }^{(30)}$ also, detected a decrease in melatonin levels in patients treated with another AED, carbamazepine (CBZ). They attributed that to the additive increase in ROS due to the disease combined with CBZ, or possibly to a difference in melatonin kinetics in conditions of oxidative stress. Li et al., ${ }^{(31)}$ reported that melatonin directly interacts with MDA to form a new product. The findings suggest that melatonin may detoxify unsaturated carbonyls and protect against cellular damage induced by oxidative stress. This is confirmed by the negative correlation between melatonin and MDA, and the positive correlation between melatonin and SOD. Gupta et al. ${ }^{(\mathbf{1 2})}$ found that administration of melatonin to AEDs, increased the antioxidant level in epileptics receiving VPA. Melatonin, thus, as an adjunct, can be a putative neuroprotector in conditions involving oxidative stress like epilepsy ${ }^{(\mathbf{1 0}, \mathbf{1 1}, \mathbf{1 2})}$.

Altered Zinc $\left(\mathrm{Zn}^{2+}\right)$ metabolism has been implicated to play a role in the development of epilepsy. Intracellular $\mathrm{Zn}^{2+}$ homeostasis is 
sensitive to patho-physiological environmental changes, such as acidosis, inflammation and oxidative stress. The mechanisms by which $\mathrm{Zn}^{2+}$ exerts its neurotoxicity include inhibition of glutamic acid decarboxylase activity, thereby resulting in decreased levels of $\mathrm{GABA}^{(32)}$, and also, production of ROS and disruption of metabolic enzymatic activity, ultimately leading to activation of apoptotic and/or necrotic processes leading to acute neuronal injury ${ }^{(33)}$. In the present study, serum $\mathrm{Zn}^{2+}$ levels showed a non-significant decrease in the untreated epileptic group, while there was a significant decrease in the serum $\mathrm{Zn}^{2+}$ level in the epileptic children receiving the VPA therapy. This could be attributed to the fact that VPA binds $\mathrm{Zn}^{2+}$, thus protecting glutamic acid decarboxylase from the inhibitory effect of $\mathrm{Zn}^{2+}$ and hence increasing the level of $\mathrm{GABA}^{(34)}$. In accordance with the present results, Lerman-Sagie et al., (35) reported reduced erythrocyte $\mathrm{Zn}^{2+}$ content in their epileptics. Kuzuya et al. $^{(36)}$ reported lower levels of $\mathrm{Zn}^{2+}$ in patients who were treated with the AED VPA. In the prospective study done by Altunbasak et al. ${ }^{(37)}$, the serum and hair levels of $\mathrm{Zn}^{2+}$ were found to be higher in untreated epileptic patients than those treated with VPA and controls. In accordance with the current results, is the work done by Steidl et al., and Armutcu et al. $^{(38,39)}$. Controversy exists, as in contrast to the current findings, Yuen et al. ${ }^{(40)}$ reported normal levels of $\mathrm{Zn}^{2+}$ in white blood cells of epileptic patients on VPA or CBZ. They suggested that AEDs might affect the intracellular $\mathrm{Zn}^{2+}$ level concentrations.

In the current study nonsignificant higher serum levels of $\mathrm{Cu}^{2+}$ in the untreated epileptic patients as compared to the control group were reported. However, there were significantly higher levels of $\mathrm{Cu}^{2+}$ in the epileptic patients receiving VPA therapy. This is in accordance with previous studies ${ }^{(\mathbf{3 9}, 41)}$. The significantly increased level of serum $\mathrm{Cu}^{2+}$ in epileptic patients receiving VPA therapy could be attributed to the influence of AEDs on the serum $\mathrm{Cu}^{2+}$ and ceruloplasmin concentrations by hepatic enzymes induction $^{(42)}$. Tutor-Crespo et al. ${ }^{(41)}$ also, reported that VPA may increase the hepatic synthesis of ceruloplasmin. Also, in some cases, a drug induced cholestasis may contribute to the increase in serum $\mathrm{Cu}^{2+}$ and ceruloplasmin. Another explanation was given by Pippenger et al., (23) who attributed the high levels of serum $\mathrm{Cu}^{2+}$ in untreated epileptics to an inverse relationship between $\mathrm{Cu}^{2+}$ and $\mathrm{Zn}^{2}$. Thus the current study indicates that $\mathrm{Cu}^{2+}$ and $\mathrm{Zn}^{2}$ homeostasis might be affected by VPA therapy, but not by the convulsive disorder itself.

However, controversy exists regarding serum $\mathrm{Cu}^{2+}$ in either untreated or treated epileptics. Hurd et al., and Kaji et al. ${ }^{(\mathbf{4 3 , 4 4 )}}$ reported decreased levels of serum $\mathrm{Cu}^{2+}$ in epileptics receiving VPA therapy ${ }^{(45)}$. On the other hand, Verotti et al. ${ }^{(7)}$ reported that VPA did not affect $\mathrm{Cu}^{2+}$ or $\mathrm{Zn}^{2}$ serum concentrations.

In conclusion, it seems possible that oxidant stress is associated with epilepsy and is aggravated with VPA 
therapy leading to relative reduction in melatonin and absolute reduction in erythroctic SOD and serum zinc concentration respectively. Thus, using melatonin and zinc (in view of their antioxidant activity) as an adjuvant therapy with VPA seems beneficial and needs thorough investigation.

\section{REFERENCES}

1. Gastaut, H. (1973): Dictionary of epilepsy, Geneva: World Health Organisation.

2. Sudha, K.; Rao, A.V. and Rao, J. (2001): Oxidative stress and antioxidants in epilepsy. Clinica Chimica Acta 303: 19-24.

3. Jesberger, J.A. and Richardson, J.S. (1991): Oxygen free radicals and brain dysfunction. Int. J. Neurosci., 57: 1-17.

4. Cengiz, M.; Yuksel, A. and Seven M. (2000): The effects of carbamazepine and valproic acid on the erythrocyte glutathione, glutathione peroxidase, superoxide dismutase and serum lipid peroxidation in epileptic children. Pharmacol. Res., 41(4): 423-5.

5. Coyle, J.T. and Puttfarcken, P. (1993): Oxidative stress, glutamate and neuro-degenerative disorders. Science 262: 689-95.

6. Ben-Menachem, E.; Kyllerman, M. and Marklund, S. (2000): Superoxide dismutase and glutathione peroxidase function in progressive myoclonus epilepsies. Epilepsy Res., 40(1): 33- 39.
7. Verrotti, A.; Basciani, F.; Trotta, D.; Pomilio, M.P.; Morgese, G. and Chiarelli, F. (2002): Serum copper, zinc, selenium, glutathione peroxidase and superoxide dismutase levels in epileptic children before and after one year of sodium valproate and carbamazepine therapy. Epilepsy Res., 48(1-2): $71-5$.

8. Srivastava, A.K.; Gupta, S.K.; Jain, S. and Gupta, Y.K. (2002): Effect of melatonin and phenytoin on an intracortical ferric chloride model of posttraumatic seizures in rats. Meth. Find. Exp. Clin. Pharmacol., 24: 145-9.

9. Mollina Carballo, A.; MunozHoyos, R. and Reiter, R.J. (1997): Utility of high dose of melatonin as adjunctive anticonvulsant therapy in a child with severe myoclonic epilepsy: two years experience. J. Pineal. Res., 23: 97-105.

10. Espinar, A.; Garcia-Olivia, A.; Isorna, E.M.; Quesada, A. and Prada, F.A. (2000): Neuroprotection from glutamate induced excitotoxicity during development of cerebellum in chick embryo. J. Pineal. Res., 28: 81-8.

11. Allegra, M.; Reiter, R.J.; Tan, D.X.; Gentile, C.; Tesoriere, L. and Livrea, M.A. (2003): The chemistry of melatonin's interaction with reactive species. J. Pineal. Res., 34: 1-10.

12. Gupta, M.; Gupta, Y.K.; Agarwal, S.; Aneja, S. and Kohli, K. (2004): A randomized double blinded, placebo 
controlled trial of melatonin addon therapy in epileptic children on valproate monotherapy: effect on glutathione peroxidase and glutathione reductase enzymes. Br. J. Clin. Pharmacol., 58(5): 542-7.

13. Srivastava, A.K.; Gupta, S.K.; Jain, S. and Gupta, Y.K. (2002): Effect of melatonin and phenytoin on an intracortical ferric chloride model of posttraumatic seizures in rats. Methods Find. Exp. Clin. Pharmacol., 24: 145- 9.

14. Gupta, M.; Aneja, S. and Kohli, K. (2004): Add-on melatonin improves quality of life in epileptic children on valproate monotherapy: a randomized, double blinded, placebocontrolled trial. Epilepsy Behav., 5(3): 316- 21 .

15. Schulpis, K.H.; Lazaropoulou, C.; Regoutas, S.; Karikas, G.A.; Margeli, A.; Tsakiris, S.; et al. (2006): Valproic acid monotherapy induces DNA oxidative damage. Toxicology 217(2-3): 228- 32.

16. Satoh, K. (1978): Serum lipid peroxide in cerebrovascular disorders determined by a new colorimetric method. Clin. Chem. Acta.,90: 37 - 43.

17. McCord, J. and Fridovich, T. (1969): Superoxide dismutase. An enzymatic method for erythrocuprein. J. Biol. Chem., 244: 6049-50.

18. Waldhauser. F.; Kovacs, J. and Reiter, E. (1998): Age-related changes in melatonin levels in humans and its potential consequences for sleep disorders. Exp. Gerontol., 33: 759 - 772.

19. Anderson, C.M.; Hallberg, A. and Hogberg, T. (1996): Advances in the development of pharmaceutical antioxidants. Adv. Drug. Res. 28:65-180. Cited in: Cengiz, M.; Yuksel, A. and Seven M. (2000): The effects of carbamazepine and valproic acid on the erythrocyte glutathione, glutathione peroxidase, superoxide dismutase and serum lipid peroxidation in epileptic children. Pharmacol. Res., 41(4): 423-5.

20. Keller, B.J.; Yamanaka, G. and Thurman, R.G. (1992): Inhibition of mitochondrial respiration and oxygen dependant hepatotoxicity by six structurally dissimilar peroxysomal proliferating agents. Toxicology 71: 49- 61.

21. Gilgun-Sherki, Y.; Rosenbaum, Z.; Melamed, E. and Offen, D. (2002): Antioxidant therapy in acute central nervous system injury: current state. Pharmacol. Rev., 54: 271- 84.

22. Weber, G.F.; Maertens, P.; Merg, $X$. and Pippenger, $C$. (1991): Glutathione peroxidase deficiency and childhood seizures. Lancet 337: 1443- 4.

23. Pippenger, C.; Merg, X,.; Van Lente, F. and Rotliner, A.D. (1989): Valproate therapy depresses GSHpx and SOD enzyme activity. A possible mechanism for valproate induced idiosyncratic drug toxicity. Clin. Chem., 35: 1173.

24. Graham, J.S.; Beran, R.G.; Kennawy, D.C.; Mc Loughney, 
J. and Matthews, C.D. (1995): Melatonin response in active epilepsy. Epilepsia 36: 75- 8.

25. Yalyn, O.; Arman, F.; Erdogan, F. and Kula, M. (2006): A comparison of the circadian rythms and the levels of melatonin in patients with diurnal and nocturnal complex partial seizures. Epilepsy Behav., 8(3): 42- 6.

26. Gupta, M.; Gupta, Y.K.; Agarwal, S.; Aneja, S.; Kalaivani, M. and Kohli, K. (2004): Effects of add-on melatonin administration on antioxidant enzymes in children with epilepsy taking carbamazepine monotherapy: a randomized, double-blind, placebo-controlled trial. Epilepsia 45(12): 1636-39.

27. Srinivasan, V . (2002): Melatonin oxidative stress and neurodegenerative diseases. Indian J. Exp. Biol., 40: 668-79.

28. Sandyk, R.; Tsagas, N. and Anninos, P.A. (1992): Melatonin as a proconvulsive hormone in humans. J. Neurosci., 63:125- 35.

29. Bazil, C.W.; Short, D.; Crispin, D. and Zheng, W. (2000): Patients with intractable epilepsy have low melatonin which increases following seizures. Neurology 55: 1746-8.

30. Gupta, M.; Kohli, K. and Gupta, Y.K. (2006): Modulation of serum concentrations of melatonin by carbamazepine and valproate. Indian J. Physiol. Pharmacol., 50(1): 79- 82.

31. Li, G.; Li, L. and Yin, D. (2005): A novel observation: melatonin's interaction with malondiadehyde.

Neuro.

Endocrinol. (Let.), 26: 61-6.

32. Ebadi, M.; Wilt, S.; Ramaley, R.; Swanson, S. and Mebus, C. (1984): The role of zinc and zincbinding proteins in regulation of glutamic acid decarboxylase in brain. In: Evangenopoulas AD, editor. Progress in clinical and biological research. Vol. 144 Part A. Chemical and biological aspects of vitamin B6 catalysis. New York: Alan R. Liss; p. 255275.

33. Capasso, M.; Jeng, J.M.; Malavolta, M.; Mocchegiani, E. and Sensi, S.L. (2005): Zinc dyshomeostasis: a key modulator of neuronal injury. J. Alzheimers Dis., 8(2): 93- 108.

34. Sheth, D.P. Hypocalcemic seizures neonates. Am. J. Emerg. Med., 15:141-143.

35. Lerman-Sagie, T.; Statter, M.; Szabo, G. and Lerman, $P$. (1987): Effect of valproic acid therapy on zinc metabolism in children with primary epilepsy. Clin. Neuropharmacol., 10:8086.

36. Kuzuya, T.; Hasegawa, T.; Shimizu, K. and Nebeshima, $T$. (1993): Effect of antiepileptic drugs on serum zinc, copper concentrations in epileptic patients. Int. J. Clin. Pharmacol. Ther. Toxicol., 31: 61-65.

37. Altunbasak, S.; Biatmakoui, F.; Baytok, V.; Herguner, O.; Burgut, H.R. and Kayrin, L. (1997): Serum and hair zinc levels in epileptic children taking valproic acid. Biol. Trace Elem. Res., 58:117-125. 
38. Steidl, L.; Tolde, I. and Svomova, V. (1987): Metabolism of magnesium and zinc in patients treated with antiepileptic drugs and with magnesium lactate. Magnesium 6: 284-295.

39. Armutcu, F.; Ozerol, E.; Gurel, A.; Kanter, M.; Vural, H.; Yakinci, C. et al. (2004): Effect of long-term therapy with sodium valproate on nail and serum trace element status in epileptic children. Biol. Trace Elem. Res., 102(1-3): 1-10.

40. Yuen, W.C.; Whiteoak, R. and Thompson, R.P. (1988): Zinc concentrations in leukocytes of patients receiving antiepileptic drugs. J. Clin. Pathol., 41: 553555.

41. Tutor Crespo, M.J.; Hermida, J. and Tutor, J.C. (2003): Assessment of copper status in epileptic patients treated with anticonvulsant drugs by measuring the specific oxidase activity of ceruloplasmin. Epilepsy Rev., 56(2-3): 147- 53.
42. Motta, E.; Miller, K. and Ostrowska, Z. (1998): Concentration of copper and ceruloplasmin in serum of patients treated for epilepsy. Wiad. Lek. 51: 156-161.

43. Hurd, R.W.; Van Rinsvelt, H.A.; Wilder, B.J.; Karas, B.; Maenhaut, W. and De Reu, L. (1984): Selenium, zinc and copper changes in valproic acid: possible correlation to drug side effects. Neurology 34: 13931395.

44. Kaji, M.; Ito, M.; Okuno, T.; Momoi, T.; Sasaki, H.; Yamanaka, C. et al. (1992): Serum copper and zinc levels in epileptic children with valproate. Epilepsia 33: 555-557.

45. Hamed, S.A.; Abdellah, M.M. and El-Melegy, N. (2004): Blood Levels of trace elements, electrolytes, and oxidative stress/antioxidant systems in epileptic patients. J. Pharmacol. Sci., 96 (4): 465-473. 


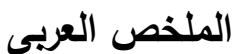

العلاقة بين مستوى الميلاتونين فى مصل الام وحالة التأكسد و مضادات الأكسدة فى الأطفال المصابين بالصرع و تأثير العقار المعالج (فالبروات)

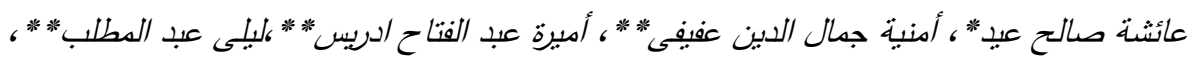
هبة السلامونى و جيهان حسين أبراهيم

قسمى الكيمياء الحيوية الطبية* والأطفال ** - كلية الطب - جامعة الطعة القاهرة

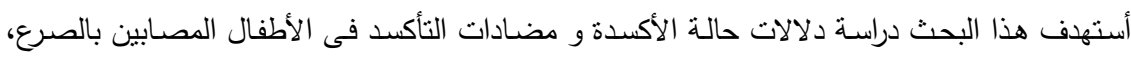

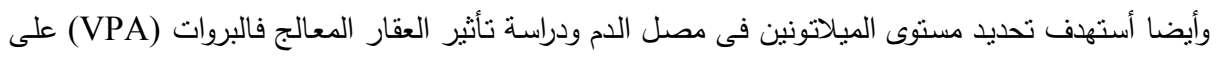

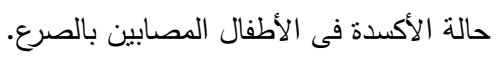
و قد شمل هذا البحث •ـ طفلا مصابين بالصرع تتراوح أعمارهم بين r سنوات و r با سنة و تم تقسيمهم الى الى مجموعتين:

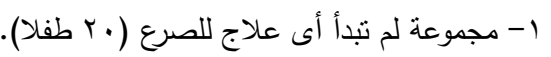

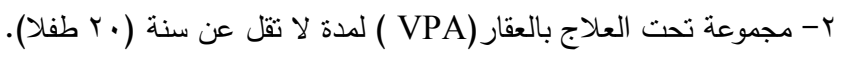
و كنلك شمل البحث 10 طفلا صحيحا كمجوعة ضابطة. وقد تم قياس الآتى فى جميع المجموعات: مستوى الميلاتونين والزنالك والنحاس والمالون الثنائى الألدهيد (MDA) كمقياس لعملية الأكسدة، والسوبر أوكسيد

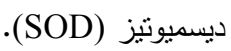

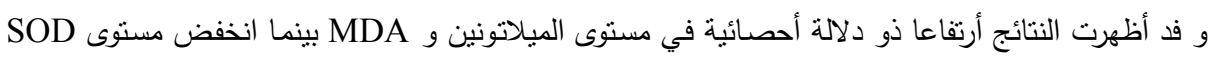

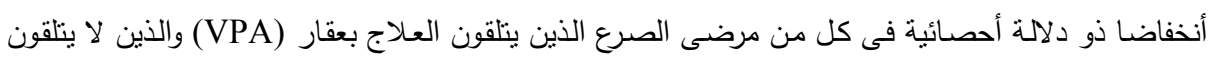

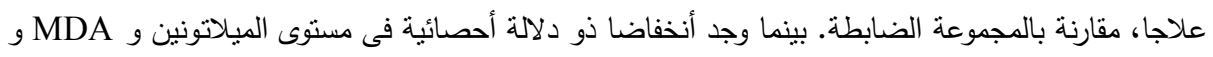

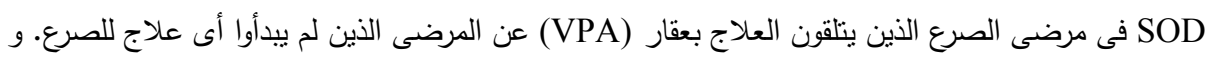

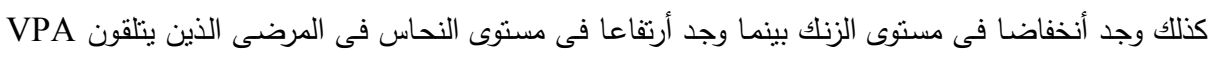

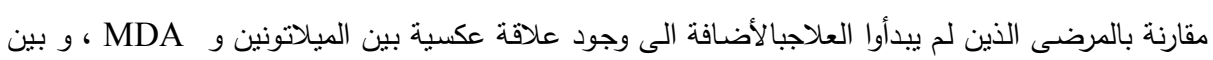

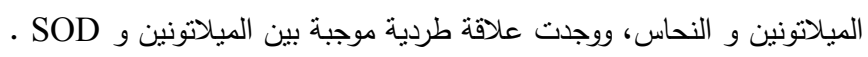

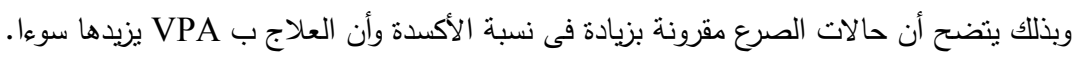

